\title{
Information Visualization (IV) Application for Information Acquisition based on Visual Perception
}

\author{
Norasikin Fabil ${ }^{1}$, Zawawi Ismail ${ }^{2}$, Zarina Shukur ${ }^{3}$, Shahrul Azman Mohd. Noah ${ }^{3}$, \\ Juhana Salim ${ }^{3}$ \\ ${ }^{1}$ Islamic Science University of Malaysia \\ ${ }^{2}$ University of Malaya, Malaysia \\ ${ }^{3}$ National University of Malaysia \\ Email: norasikinfabil@yahoo.com,zawawiismail@um.edu.my,za@ftsm.ukm.my, \\ samn@ftsm.ukm.myjs@ftsm.ukm.my
}

Received 2012

\begin{abstract}
Information Visualization (IV) is a current field that has the potential to develop methods of accessing, processing and managing of information (Chen \& Czerwinski, 2000). IV applications are developed as a learning tool due to the technique of IV being capable of improving the understanding process through the use of visuals. In addition, IV applications are also able to manage the several data sources and complex concepts in learning activities. IV techniques are useful for information acquisition and learning activities. Based on the theory of visual perception, this study produces a design of IV application. The design supports a particular understanding of the visual accordance with data of the hadith environment. Balance to the visual design can build a good human perceptual system to understand the concepts and interpret information more easily and accurately. The findings of the study show the good interpretation and the high score of respondents' achievement toward using the application. This result indicates that the contribution of visual perception theory as the design of the IV application can create a better visual perception and enhance the quality and quantity of the information.
\end{abstract}

Keywords: Visual; Visual Perception Theory; Information Visualization (IV)

\section{Introduction}

Visuals have become important in communicating information in various fields. The field of advertising uses visuals as an agent to convey information effectively. Similarly, the fields of medicine, management and business are using visual materials as a tool in their operations. Similarly, in education, visuals play a very important role in teaching and learning as a tool for information, motivation and explanation.

In the past, the use of visual was limited to printed materials; technology is a catalyst for change and development in the visual presentation of information and knowledge. Technology makes visual communication devices impart information and knowledge more quickly and effectively. The technology exists to build an environment that is more interesting and interactive in order to increase the ability of sensory points to identify rapidly and easily scan through a visual display with visual characteristics of good shape, color and composition.

This introduction shows the growing use of visuals to fulfill various needs and interests. Visuals are not only seen as interesting, they facilitate the acquisition and understanding of information in a shorter period. Use of visual is built on the theory that supports the use of faster and more effective processing. This paper discusses the study of using Information Visualization (IV) application based on visual perception theory that supports a better acquisition of information in teaching and learning purposes.

\section{Purpose of Study}

The aimed of this study is to study the usability of IV appli- cation for using in Science of Hadith and to evaluate the effect of visual perception towards using of the application.

\section{Background of the Study}

The visuals advantages and requirements for information acquisition in Science of Hadith are discusses as the background of study. The visuals contribute the design of IV application and create a better visual perception and understanding of the information inside of the application.

\section{Visuals Ability}

Visuals play a leading role in the dissemination of information and knowledge. Visuals can be used to convey an existing idea or to create, produce and cover new ideas. Visuals also enable abstract information to be conveyed more clearly.

Based on the use of visuals to represent and present information, visuals are usually used to describe visual concepts, ideas and processes. Even the visual splendor can be used to stimulate interest and effective understanding.

Spence (2001) gave a few ideas to state the advantages of visuals, including:

- Visuals are tools for exploiting human perception.

- Visual perception is a powerful and rapid exploitation.

- Visual able to change the structure of the task.

- Visual cognitive change can happen to a perception by perception.

- Perception by the perception that happens involves interaction between people and to create a visual representation of the 
internal view and develop an understanding of information and knowledge to be transferred.

- Visual is a crystallization of information.

\section{Visual Represent the Data of Application}

In this study, visual ability is adapted to the environment of science of hadith. The focus is on the narrators of Hadith who present material (content of Hadith) and the sanad or chain of transmission or link between the narrators of Hadith (Atikullah, 2005; Nawer, 2003; Subhi Salih, 1993).

At present, knowledge of hadith related information may be obtained in writing or electronically. But technology use in hadith sciences is still relatively limited. Material is relatively easily available in electronic form. Source of data on the narrator is still limited. Information can be obtained on a variety of narrators in the dictionary of narrators. While the relationship with the Hadith is something to be achieved through the Hadith books such as Sahih Muslim and Sahih al-Bukhari, information and chain of transmission (sanad) occurs through many narrators and their relationship is quite complex. The complex process of data acquisition took a long time. But in this study, the use of visual presentation of information is designed to reflect the knowledge of Hadith transmission.

Borner et al. (2003) states that the traditional method makes it difficult for members of that knowledge to sort data based on the literature. Traditional methods involve time and increase errors and data duplication. Small (2000) also stated that the intersection of disciplines shows sensitivity to the wider review of the creative imagination and manipulation of external information or information in other fields to solve an existing problem. The effort in the acquisition of knowledge of hadith is seen as an effort to preserve the well-protected sanad based on love for the traditions of the Prophet (blessings and peace be upon him).

This study suggests that each image of the object is seen with its own set of visual features. Differences in feature set of objects have great impact on the identification of an object. Objects that have different features to help the identification are processed much faster. The researcher believes that in line with the view of Healey (2007), development of information visualization application need to take into account the interests of Theory of Visual Perception that show a high contribution in influencing the process of identifying visual images seen.

This study suggests that appropriate visual design can assist in the identification and perception of visual information via the visualization application. Visual design can affect components of the human visual system capable of low level visual identification on a regular and accurate rate of visual basic characteristics such as color, shape and line.

\section{Methodology}

The usability testing of heuristic (Hui, 2002) are the methodology of this study. According to Hui (2002), usability is a part of system acceptability however usability is more focused on the interface of system. Meanwhile, heuristic is one of the methods of system evaluation bases on expert evaluation that focus on the system design with the usability principles. This study uses the adaptation of usability testing and heuristic as suggested by Hui that mentioned adaptation of evaluation method is needed to evaluate the application.

There are 8 metrics of heuristic evaluation which are system interaction, conciseness, retention, coherence, consistency, comprehensibility, fit for audience and fit for purpose. For this study, the evaluation basis on the visual design is stated in the 5 metrics of heuristic which are conciseness, retention, coherence, consistency, comprehensibility as shown in Table $\mathbf{1 .}$

There are two types of instruments which are survey towards the visual design of the application after using the application and observation form towards the reflection on their learning process using the application. This study involves 241 students as respondents to respond on the metric of heuristic. Meanwhile, 20 of them are selected by randomly as respondents to respond on the effect of visual design toward learning science of hadith knowledge.

\section{Application Design of Visual Perception Theory}

The application design images be used to help people compare the target image with the image environment. Humans also make comparisons based on the characteristics belonging to a visible image. There are visual interpretation processes that can be done more quickly and effectively based on the design of image development. This study suggests that appropriate design be developed to suit the type of data in the field of Hadith. The application uses a different image and in line with the objective of development of the application it can help identify and make reference in the interpretation of the narrator and the chain of transmission sanad as example shows in Figure 1.

\section{Findings}

This paper discusses two types of finding. The first finding discusses on the usability of the Hadith visualization application basis on the 5 metrics of heuristic which are conciseness, retention, coherence, consistency, comprehensibility. The second finding discusses on the effect of learning science of hadith knowledge using the Hadith visualization application.

Table 1.

Metrics of heuristic for usability evaluations.

\begin{tabular}{lll}
\hline No $\quad$ Metrics of Heuristic & Description \\
\hline 1. $\quad$ The chain of the narrators stated \\
precisely although narrator have \\
overlap sanad and hadith. Information \\
displayed naturally according to hadith \\
narrated.
\end{tabular}




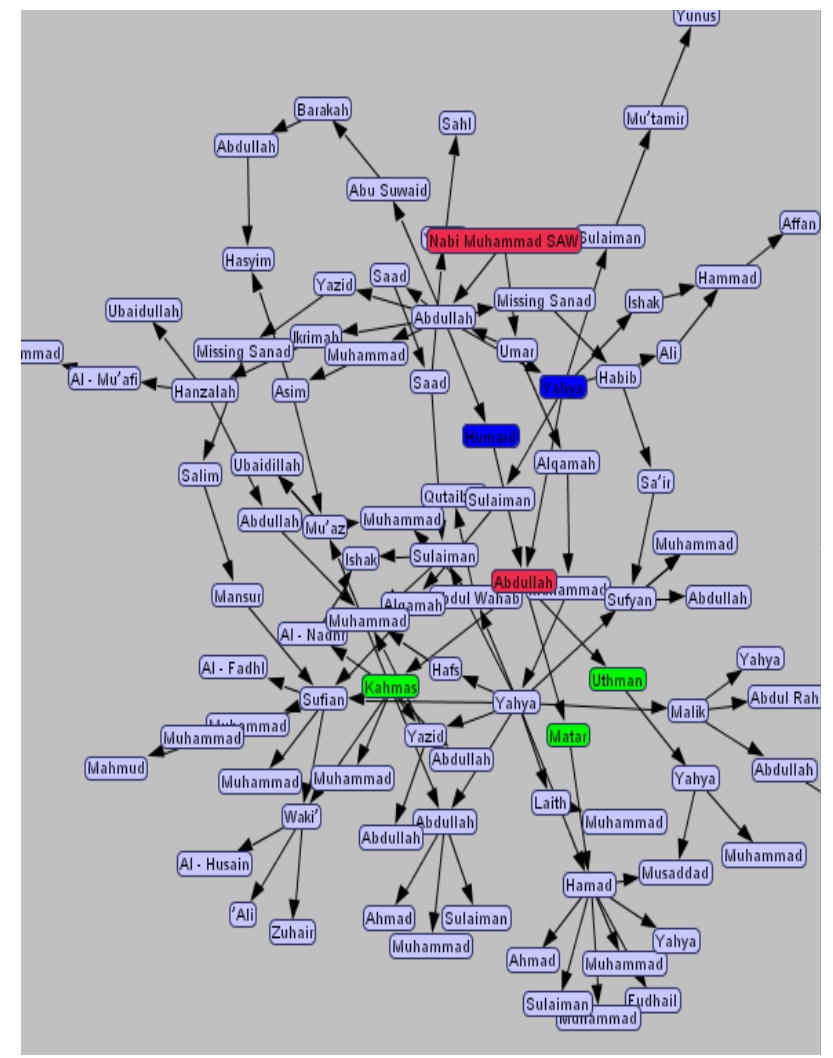

Figure 1.

Interface of the IV application.

Table 2 shows the result of usability evaluation of Hadith visualization application based on the heuristic metric. There are 20 items consists in the 5 metrics. Each of the metrics is measuring the application design and the interface of the application.

The finding shows interpretation of overall mean is strongly agreed $($ mean $=4.2$ ). The result shows that respondents strongly agreed the uses of hadith visualization application basis on the visual design. The first of heuristic is conciseness $($ mean $=4.16)$ mean that the visual design of the application shows the chain of the narrators stated precisely although the narrators have received more than one hadiths. The heuristic of retention (mean $=4.25$ ) shows the visual design is simple representation but strongly facilitate data mapping in mind. Meanwhile coherence (mean $=4.14$ ) shows the application design have the continuity of information that facilitates data achievement, understandable, clear and easy to get overall idea from the display. Consistency (mean $=4.17$ ) shows respondents strongly agreed the visual design of icon and feature of data representation facilitate user understand application without any confusion. The fifth of heuristic metric comprehensibility scored the highest (mean $=3.21$ ) shows the interface of application is readily understandable where visual design support comprehension process and chain pattern of the sanad in hadith domain.

For the second finding, 20 of the respondents are selected by randomly to respond on the effect of learning Science of Hadith using the Hadith application visualization. The students have used the application and answered the questions related to data of the application orally. A schedule of observation is used as instrument to analyze the respondents' achievement as the ef- fect of learning science of hadith knowledge using the application.

Table 3 shows the high score (overall mean $=4.95$ ) of respondents' achievement in learning Science of Hadith using the application. This result indicates the hadith visualization application has affected the learning process. The respondents have produced the best attention, recognition and memorize the data of the sanad and narrators using the application. In addition this result indicated the visual design based on the theory of visual perception is accordance with data of the hadith environment. The visual designs of the application have built a good human perceptual application for the students to understand the concepts and interpret information of the sanad and narrators easily and accurately.

Table 2.

Finding of usability evaluations.

\begin{tabular}{ccc}
\hline Metrics of Heuristic & Mean & Interpretation \\
\hline Conciseness & 4.16 & Strongly agreed \\
Retention & 4.25 & Strongly agreed \\
Coherence & 4.14 & Strongly agreed \\
Consistency & 4.17 & Strongly agreed \\
Comprehensibility & 4.31 & Strongly agreed \\
Overall mean & 4.20 & Strongly agreed \\
\hline
\end{tabular}

Table 3.

Findings on respondents' achievement toward application.

\begin{tabular}{|c|c|c|c|c|c|c|}
\hline Items & $1 \%$ & $2 \%$ & $3 \%$ & $4 \%$ & $5 \%$ & Mean \\
\hline Identify the sanad & $\begin{array}{c}0 \\
0 \%\end{array}$ & $\begin{array}{c}0 \\
0 \%\end{array}$ & $\begin{array}{c}0 \\
0 \%\end{array}$ & $\begin{array}{c}1 \\
5 \%\end{array}$ & $\begin{array}{c}19 \\
95 \%\end{array}$ & 4.95 \\
\hline $\begin{array}{l}\text { Make an overall analysis } \\
\text { using visual sample given }\end{array}$ & $\begin{array}{c}0 \\
0 \%\end{array}$ & $\begin{array}{c}0 \\
0 \%\end{array}$ & $\begin{array}{c}0 \\
0 \%\end{array}$ & $\begin{array}{c}2 \\
10 \%\end{array}$ & $\begin{array}{c}18 \\
90 \%\end{array}$ & 4.9 \\
\hline Identify the narrator & $\begin{array}{c}0 \\
0 \%\end{array}$ & $\begin{array}{c}0 \\
0 \%\end{array}$ & $\begin{array}{c}0 \\
0 \%\end{array}$ & $\begin{array}{c}0 \\
0 \%\end{array}$ & $\begin{array}{c}20 \\
100 \%\end{array}$ & 5 \\
\hline $\begin{array}{l}\text { Identify the information of } \\
\text { narrator }\end{array}$ & $\begin{array}{c}0 \\
0 \%\end{array}$ & $\begin{array}{c}0 \\
0 \%\end{array}$ & $\begin{array}{c}0 \\
0 \%\end{array}$ & $\begin{array}{c}0 \\
0 \%\end{array}$ & $\begin{array}{c}20 \\
100 \%\end{array}$ & 5 \\
\hline $\begin{array}{l}\text { Doing analysis of the } \\
\text { narrator's information }\end{array}$ & $\begin{array}{c}0 \\
0 \%\end{array}$ & $\begin{array}{c}0 \\
0 \%\end{array}$ & $\begin{array}{c}0 \\
0 \%\end{array}$ & $\begin{array}{c}0 \\
0 \%\end{array}$ & $\begin{array}{c}20 \\
100 \%\end{array}$ & 5 \\
\hline $\begin{array}{l}\text { Identify the relationship } \\
\text { between the narrator } \\
\text { (sender and retriever) }\end{array}$ & $\begin{array}{c}0 \\
0 \%\end{array}$ & $\begin{array}{c}0 \\
0 \%\end{array}$ & $\begin{array}{c}0 \\
0 \%\end{array}$ & $\begin{array}{c}0 \\
0 \%\end{array}$ & $\begin{array}{c}20 \\
100 \%\end{array}$ & 5 \\
\hline $\begin{array}{l}\text { Identify the narrator based on } \\
\text { the total of narratored hadith }\end{array}$ & $\begin{array}{c}0 \\
0 \%\end{array}$ & $\begin{array}{c}0 \\
0 \%\end{array}$ & $\begin{array}{c}0 \\
0 \%\end{array}$ & $\begin{array}{c}0 \\
0 \%\end{array}$ & $\begin{array}{c}20 \\
100 \%\end{array}$ & 5 \\
\hline $\begin{array}{l}\text { Analysis of the sanad's chains } \\
\text { based on the narrator }\end{array}$ & $\begin{array}{c}0 \\
0 \%\end{array}$ & $\begin{array}{c}0 \\
0 \%\end{array}$ & $\begin{array}{c}0 \\
0 \%\end{array}$ & $\begin{array}{c}1 \\
5 \%\end{array}$ & $\begin{array}{c}19 \\
95 \%\end{array}$ & 4.95 \\
\hline $\begin{array}{l}\text { Remember the information } \\
\text { of narrator }\end{array}$ & $\begin{array}{c}0 \\
0 \%\end{array}$ & $\begin{array}{c}0 \\
0 \%\end{array}$ & $\begin{array}{c}1 \\
5 \%\end{array}$ & $\begin{array}{c}1 \\
5 \%\end{array}$ & $\begin{array}{c}18 \\
90 \%\end{array}$ & 4.85 \\
\hline Remember the sanad & $\begin{array}{c}0 \\
0 \%\end{array}$ & $\begin{array}{c}0 \\
0 \%\end{array}$ & $\begin{array}{c}1 \\
5 \%\end{array}$ & $\begin{array}{c}2 \\
10 \%\end{array}$ & $\begin{array}{c}17 \\
85 \%\end{array}$ & 4.8 \\
\hline Overall mean & & & & & & 4.95 \\
\hline
\end{tabular}




\section{Discussion and Conclusion}

The emergences of IV applications are managed to handle the huge data sources and complex concepts in learning activities. Furthermore, application of visualization is useful for acquisition of information and learning activities. This study indicated that visual design in application visualization based on the Theory of Visual Perception supports a particular understanding of the visual in the application. The visualization application provides the pattern of the data to make the students understand the concepts and interpret information more easily and accurately which as mentioned by Rheingans and Ebert (2001). This study also synchronizes with Healey (2007) where the understanding of human perception can enhance the quality and quantity of the information.

Based on the capability of human visual perception, this study suggests the design that is appropriate with the objectives of visualization itself, namely to allow in depth vision and not just peripheral vision. In-depth vision means the visual can give information that is clear, integrated and contributes to decision-making. This study contributes the suggestion of using information visualization in domain knowledge of Sciences of Hadith.

\section{REFERENCES}

Atikullah Hj. Abdullah. (2005). Rehlah Ilmiyyah dan Kepentingannya: Refleksi Dari Tradisi Para 'Ulama' Hadith Islam. Pulau Piang: Penerbit USM.

Borner, K., Chen, C. \& Boyack, K. (2003). Visualizing knowledge domains. In B. Cronin (Ed.), Annual Review of Information Science \& Technology, 37, pp.179-255.

Card, S. K., Mackinlay, J. D., \& Shneiderman, B. (1999). Readings in information visualization: Using vision to think. San Francisco, CA: Kaufmann.

Chen, C. \& Paul, R. J. (2001). Visualizing a knowledge domain's intellectual structure. Computer, 34(3), 65-71.

Chen, C. (2003). Visualizing scientific paradigms: An introduction. Journal of the American Society for Information Science and Technology, 54(5), 392-339.

Chen, C. (2004). Information visualization: Beyond the horizon (2nd ed.). London: Springer.

Duncan, J., \& Humphreys, G. W. (1989). Visual search and stimulus similarity. Psychological Review (96)3, 433-458.

Healey, C. G. (1995). Choosing effective colours for data visualization. Proceedings Visualization '95, pp. 263-270.

Healey, C. G. (2001). Formalizing artistic techniques and scientific visualization for painted renditions of complex information spaces. Proceedings International Joint Conference on Artificial Intelligence (IJCAI 2001) (pp. 371-376).

Healey, C. G. (2007). Perception in Visualization. Retrieved from http://eeeeleranspace.org/articles/InstructinalDesign.htm[9 Julai 2011] http://en.scientificcommons.org/xavier_polanco [27Oktober2008] http://www.csc.ncsu.edu/faculty/healey/PP/index.html. http://www.personal.psu.edu/faculty/s/jsjm256/portfolio/kbase/IDD/I SDModels.html. [3 Mac 2011]

Hui, B. (2002). Developing and evaluating a document visualization system for information management. Ph.D Thesis, University of Toronto.

Ishak Haji Suliaman. (2007). Isnad Hadis sebagai etika maklumat Islam. Dlm. Ishak Haji Suliaman, Fauzi Deraman, Mohd. Muhiden Abd Rahman \& Abdul Karim Ali, Autoriti Hadis menangani gerakan antihadis (hlm. 47-59). Kuala Lumpur: Penerbit Universiti Malaya. Suliaman???

Jul'esz, B. (1984). A brief outline of the texton theory of human vision. Trends in Neuroscience, 7(2), 41-45.

LaConte, R. T. (1984). Communication skills for the future. Journal of Technology Teacher, 44(3), 4-5.

Lamping, L., \& Rao, R. (1994). Laying out and visualizing large trees using a hyperbolic space. Proceedings of the ACM Symposium on User Interface and Technology (UIST'94), (pp. 13-14).

MacKinlay, J. D. 1986. Automating the design of graphical presentation of relational information. ACM Transaction on Graphics 5(2): $110-141$.

McCormick, B. H., DeFanti, T. A., \& Brown, M. D. (1987). Visualization in scientific computing: Report of The NSF Advisory Panel on Graphics, Image Processing and Workstations.

McGriff, S. 2001. Instructional systems design models. http://www.personal.psu.edu/faculty/s/jsjm256/portfolio/kbase/IDD/I SDModels.html. [3 Mac 2012]

McGriff, S.J. (2000). Instructional Systems. College of Education, Penn State University.

Mergel, B. (1998). Instructional design \& learning theory. In Educational communications and technology. University of Saskatchewan.

Nawer Yuslem. (2003). Ulumul hadis. Jakarta: Penerbit Mutiara Sumber Widya.

Norasikin Fabil. (2009). Aplikasi Teknik Graph View dalam Pemvisualan Maklumat Sanad Domain Ilmu Hadis. Ph.D Thesis. Universiti Kebangsaan Malaysia, Bangi.

Polanco, X. \& Zarti, A. (2008). Information visualization, State of the art part C: WP9, EICSTES Project-IST-1999, 2008.

Rheingans, P. \& Ebert, D. S. (2001). Volume illustration: Nonphotorealistic rendering of volume models. IEEE Transactions on Visualization and Computer Graphics 7, 3 (2001), 253-264.

Siemens, G. 2002. Instructional design in E-learning.

http:// eeeeleranspace.org/articles/InstructinalDesign.htm [9 Julai 2010]

Small, H. (2000). Charting pathways through science: Exploring Garfield's vision of a unified index to science. In B. Cronin \& H. Atkins, H. (Eds.), The web of knowledge: A Festschrift in honor of Eugene Garfield (pp. 449-473). Medford, NJ: Information Today.

Spence, R. (2001). Information visualization (2nd ed.). Harlow, UK: Addison-Wesley.

Subhi Salih. (1993). Ilmu hadis: Satu pengenalan dan kajian (Terj. Ariffin Omar \& Mohd. Nor Ngah). Kuala Lumpur: Dewan Bahasa \& Pustaka.

Sweller, J. (2001). Visualization and instructional design (pp. 1501 1510). Australia. University Of New South Wales.

Treisman, A. (1985). Preattentive processing in vision. Computer Vision, Graphics, and Image Processing, 31, 156-177.

Triesman, A., \& Gormican, S. (1988). Feature analysis in early vision: Evidence from search asymmetries. Psychological Review, 95(1), $15-48$.

White, H. D., \& McCain, K. W. (1997). Visualization of literatures. In M. E. Williams (Ed.), Annual Review of Information Science and Technology, 32, pp. 99-168. Medford, NJ: Information Today.

Wolfe, J. M. (1994). Guided Search 2.0: A revised model of visual search. Psychonomic Bulletin \& Review, 1(2), 202-238. 